\title{
Kelly Jordan*
}

\section{The Ethics of Participation and Participation Gone Wrong}

https://doi.org/10.1515/jcde-2019-0021

\begin{abstract}
This article examines the way that ethics underpin and affect audience participation in contemporary theatre, illustrated in the performance practice of British-German ensemble Gob Squad. It looks at how a proliferation of participatory practices has opened up a space for ethics to be reconfigured, and establishes that the ethics of participation may intimate that a 'good' performance is interchangeable with the idea of an 'authentic' performance. It emphasises a double dimension to the ethics of participation: the first is concerned with the self and the second is about everyone else, drawing on the corresponding theories of Nicholas Ridout (2009) and Erving Goffman (1959). Importantly, the article disentangles participation gone wrong and brings into view a new categorisation of spectator which I am calling the 'dis-spectator,' who deliberately challenges the structures and processes of the performance. At the centre of the discussion are a group of hecklers in the audience of Gob Squad's War and Peace (2016), and their targeted jeering at a participant-spectator. My analysis develops a taxonomy of dis-spectatorship that outlines varying levels of transgressive behaviour from testing out the boundaries of participation to sabotaging the performance. Lastly, I call attention to a lack of consideration given to care and responsibility in participatory practices, which can leave participants in a precarious position.
\end{abstract}

Keywords: Gob Squad, audience participation, ethics, emancipated spectator, authenticity, Jacques Rancière, Erving Goffman

On 8 June 2016, I attended a performance of War and Peace by British-German collective Gob Squad at the Nottingham Playhouse. The devised production is a modern day attempt to address one of Leo Tolstoy's concerns: "if it is possible to live a moral life in an ethically imperfect world?” (Gob Squad, “Current Projects”). The premise for the performance is that a group of artists are holding a salon, reminiscent of the gatherings conducted in high society Russia at the beginning of the nineteenth century. The topic of conversation is War and Peace (1869), a

*Corresponding author: Kelly Jordan, De Montfort University Leicester,

E-Mail: kjordan@dmu.ac.uk 
'heavy' book written a century and a half ago, and how the novel intersects with contemporary society.

Before the audience are let into the theatre, the performers emerge out of the entrance and begin to mingle and interview awaiting spectators. Once inside the auditorium, the performers begin to take to the stage with their interviewees and recount into a microphone a series of facts about them, beginning with their name and where they come from and progressing to details about their special talent or father's occupation. From the interviewees, a small group of spectators is invited to join Gob Squad in the salon. They are motioned towards a table at the front of stage right and offered a seat and a glass of fine champagne. Here the participantspectators will observe and contemplate their relationship to the performance while being filmed and projected on to large screens on stage. Over the course of the evening, the audience are introduced to a procession of characters from War and Peace and beyond, as scenes unfold from shifting viewpoints. At regular intervals the Gob Squad performers ask the salon participants about their own perception of war, freedom and privilege.

It was during a Q\&A exchange between a performer and participant that I witnessed a striking example of what I am calling 'participation gone wrong,' in reference to those moments when spectators divert from their intended role and the parameters for participation set out by the practitioner. The incident involved a group of hecklers in the audience and their targeted jeering at an overly zealous participant. This moment highlighted the precarious relationship between ethics and participatory performance and brought acute attention to the emergence of transgressive audience behaviour.

Performances by Gob Squad are in part distinguished by the way that "the audience are often asked to step beyond their traditional role as passive spectators and bear witness to the results” (Gob Squad, “About Us”). Reflecting on my own bearing witness of this stepping beyond, this essay will critically examine the role that ethics play in supporting and troubling audience engagement in Gob Squad's work, specifically in relation to their productions of War and Peace (2016; still ongoing) and Western Society (2013; still ongoing). Alongside my analysis of their practice, I will also draw on the insights gained in an interview that I conducted with Gob Squad performer Sharon Smith in July 2016.

Gob Squad, founded at Nottingham Trent University in the early 1990s, have largely been overlooked within compendiums on participatory performance. While Claudia Georgia's book Liveness on Stage: Intermedial Challenges in Contemporary British Theatre and Performance (2014) thoughtfully explores the copresence of performers and spectators within a number of Gob Squad's productions, the practice is analysed in the context of intermediality rather than ethics and does not include the two case studies at the centre of my examination. This 
article aims to highlight that Gob Squad continues to be at the forefront of experiments with the audience in contemporary British theatre, as illustrated by the productions under discussion.

In Ethical Speculations (2015), Mireia Aragay acknowledges that theatre studies scholarship has been a latecomer to discourse on ethics within the humanities (Aragay and Monforte 3). Nicholas Ridout's monograph Theatre and Ethics (2009) is the first book to address the topic directly. Ridout suggests that one might think about ethics as the process of working out on what basis we decide what is good or bad, and what gives us the capacity to make those judgements (Theatre and Ethics 11). However, this calculation is especially complex for participant-spectators, as “alongside the 'parts' created for us by the performers are other habitual, sticky roles, including that of spectator" (Heddon, Iball, Zerihan 121). This raises the issue of how participants judge their performance and the performance. Additionally, how do watching-spectators evaluate their experience, and what and who is being critiqued? As my analysis will evidence, the status of ethics and aesthetics within participatory work can be a source of tension for audience members. Furthermore, it has been the focus of much academic debate (Jacques Rancière, The Emancipated Spectator; Claire Bishop, Artificial Hells; Jen Harvie, Fair Game; Gareth White, Audience Participation; and Adam Alston, Beyond Immersive Theatre).

From the early 2000s onwards, there has been a burgeoning interest in audience participation from theatre and performance makers, curators, academics and commentators. Nevertheless, there is a dearth of research dedicated to how ethics is constituted within participatory performance, and the ways in which this can be unsettled by varying forms of transgressive spectatorship. This article aims to make an original and significant contribution to knowledge in the fields of theatre and performance by addressing these essential areas of study.

Over the course of the paper, I will construct a theoretical framework for the study of ethics in participatory performance by bringing together multiple perspectives and critical concepts emerging from theatre and performance studies, the contemporary visual arts, and philosophy, in dialogue with my embodied experiences as a spectator. Together these varying insights aim to advance understanding of the complex interrelationship between ethics and audience participation. I begin by recognising that the ethics of spectatorship in performance has evolved from the theatre etiquette of the late nineteenth century (see Heim 6484) to a less certain conception within contemporary theatre today. As the argument advances it considers how Gob Squad's work responds to the ethical debate surrounding the delegation of labour to spectators, the perception of participation as a "luxury game" (see Bishop, "Outsourcing Authenticity" 114), and the paradoxical staging of authenticity. In order to offer a deeper understanding of how 
ethics is manifested in participatory performance, I will explicate a double dimension to the constitution of ethics, underscored by both the 'spectator within' and 'ethics as encounter,' drawing on the writing of Nicholas Ridout (2009) and the corresponding concepts offered by Erving Goffmann (1959).

Later, I will examine those occasions when spectators re-configure their relationship to participation, unsettling the ethical framework for the performance. My analysis will highlight three types of transgressive spectatorship; the 'mis-spectator' as defined by Ridout (2012), the 'errant spectator' identified by Adam Alston (2016), and my own definition of the 'dis-spectator.'

The term 'dis-spectator' echoes Ridout's modelling of the 'mis-spectator,' while distinguishing a new categorisation of audience member who deliberately challenges the structures and processes of the performance. The 'dis' derives from the term 'dissent' and the closely related 'dissident' to denote a spectator who has dissented from the majority of the audience to exceed or to disrupt the limits of participation. Indeed, one might also observe a correlation with the slang expression 'diss' as shorthand for 'disrespect' and to classify a put-down. However, typically the dis-spectator operates at a playful level, with a view to have a bit of fun rather than to 'diss' the performance (cause offence) or to create discord. A degree of openness in the composite meaning of 'dis-spectator' takes into consideration that this mode of transgression exists on a continuum and is informed by a range of motivations. In this regard, I have developed a taxonomy of dissident spectatorship that outlines varying levels of transgressive behaviour from testing the boundaries of participation to sabotaging the framework that maintains the performance. Lastly, my analysis will call attention to a lack of consideration given to care and responsibility in participation, which can leave participants in a vulnerable position.

\section{Towards an Ethics of Participation}

Ethics permeates all aspects of participatory performance; from the aspiration to give the audience increased freedom, to the code of practice that governs their interaction, and the standards by which the performance is valued. In turn, participation raises the ethical stakes in contemporary theatre and performance, producing some of the most exciting and dynamic art forms and experiences of the twenty-first century. Acknowledging that ethics are foundational to participatory work, frequently underscored by a moral imperative towards a democratising of the art-making process (Bishop, Participation 12), it is important to look at what kind of ethics is being promoted.

Ethical frameworks are often founded on social consensus; thus, how to act is typically fairly prescriptive. Theatre etiquette is the most recognisable system of 
ethical behaviour in performance. Its origins are consistent with, but not limited to, the introduction of electric lighting in theatres in the 1880s. The ability to lower the houselights on the audience resulted in their previously noisy and demonstrative behaviour being faded into the darkness (Heim 64). By the latter half of the twentieth century, laughter and applause were typically the only permissible signs of audience engagement with a performance. However, the growth of participatory practices from the late 1990s onwards has served to rethink audience behaviour, casting theatre etiquette or ethics into a period of uncertainty.

This does not mean that spectatorship in these works is without rules. On the contrary, participation is underpinned by a tacit agreement that spectators will accept the rules of the performance. But, these rules are usually specific to an individual performance or artist/company's style; therefore, they are lacking the same level of convention for the audience. Still, at the same time, there is a strong impulse to "give good audience" and to participate in normative assumptions about the work, perhaps invoking the notion of an "ideal audience-participant" (Heddon, Iball and Zerihan 124).

There are also times when the instructions for a participatory work are deliberately opaque or open to interpretation, in an attempt to offer greater agency to the spectator. According to Ridout: "It is in the situation of doubt, in the moment of choice, when you ask yourself, 'How shall I act?', that you are opening up the space of ethics" (Theatre and Ethics 12). Similarly, Tony Fisher contends that participation has the capacity to interrogate "the arraignment of power" by opening up a "space of speech" (25): an opening where established structures are suspended to allow alternative models of democratic politics and resistance to be realised. Moreover, it can be reasoned that it is amidst this ethical ambiguity that one finds the 'antagonism' that Claire Bishop has called for in socially engaged art (see Bishop, “Antagonism”).

As Ridout observes, social engagement is an area of convergence between theatre and ethics, as theatre regularly dramatises moral and social issues (Theatre and Ethics 13). He states: "Theatre inserts its ethical questions into the lives of its spectators in a situation in which those spectators are unusually conscious of their own status as spectators, and thus as people who may exercise ethical judgement" (15). Indeed, the meeting of theatre and ethics underpins the framework for participation in Gob Squad's War and Peace, with performers posing a series of principled questions to the salon participant-spectators. These questions included: "Two-hundred years from now, what do you think the writers of 2216 will say about these times that we are living in?" The dual position of making a judgement at the same time as being judged heightens the participant's awareness of their social responsibility and serves to magnify the potency of ethics in performance. What is more, it unsettles the established distinction between the 
one who 'acts' and the one who 'judges' in the theatre, distinguished by the roles of 'performer' and 'spectator.'

It can be said that the reconfiguration of these parts has served to democratise and revitalise the contemporary theatre scene. Nonetheless, there is a developing scepticism about the so-called “emancipated spectator," to use Rancière's term, and their role as co-producer of the performance. Rancière has observed an increasing tendency amongst contemporary practitioners to get the spectator to do something, to move from being passive to active, even if they don't know exactly what they want the spectator to do ("Emancipated Spectator" 277). He has led the charge to contest the presupposition that a participant-spectator is an emancipated-spectator. In doing so, Rancière has challenged the way in which the established binary oppositions of "viewing/knowing, appearance/reality, activity/passivity" render "the spectator seated in her place as inactive" (The Emancipated Spectator 12).

Following Rancière, Matthew Reason considers: "in the legacy of an overly comfortable binary between active and passive spectatorship" there is a belief that: "performances that engage audiences actively through participation also emancipate and empower and are consequently radically liberating” (272). In actuality, participation is frequently subject to imposed sanctions by the practitioner, and there are varying levels of agency offered to spectators. In this way, participatory works can be prescriptive and stage the spectacle of agency, rather than a more revolutionary agentive experience.

Furthermore, as participation becomes normalised through its growing popularity and the emergence of "expert participant-spectators" (see Jordan 112-113), the space of ethics may well be closing. Reflecting on participation, Bishop recalls "[y]ou hear yourself speaking in clichés, unable to break the conceptual structure that the artist has set in place" ("Outsourcing Authenticity" 120). In short, just as a mainstream audience has learnt how to perform its role through watching the behaviour of other audience members and abiding by the given rules of theatre etiquette, spectators of participatory theatre can also find themselves performing in predetermined ways.

\section{Ethics, Delegated Performance and Authenticity}

As Jen Harvie has observed, in contemporary theatre "audiences are increasingly regularly called on to participate in, contribute to and at least co-create the performance also for free and sometimes, more precisely, at the cost of a fee" (28). Although, she is quick to acknowledge that in many instances, audience members are not so much "passively exploited" as "actively exploit" the opportunity to be performing-spectators and part-time artists (28, emphasis original). 
Gob Squad was an early adopter of audience participation in contemporary performance, beginning with their piece Room Service in 2003. In my interview with Gob Squad performer Sharon Smith (a core member of the company since 2007), she recalled that: "[w]e wanted to bring the real world inside the theatre, or still have a connection to the outside via some sort of media or technology which would allow this leak. And that eventually became the audience themselves" (2). Gob Squad's approach corresponds with a reconsideration of 'authenticity' by contemporary artists, as noted by Bishop, which mobilised a shift away from the artist's body towards "delegated performance" and "outsourcing authenticity" by using other people's bodies ("Outsourcing Authenticity" 110). This reassessment of authenticity is indicative of the way that this term and the related notions of being real, true and genuine are mutable and contested concepts. My usage of the term authenticity is consistent with Bishop's reading, while also recognising an adjusted form of authenticity when authenticity is performed.

Delegated performance would appear to exemplify sculptor and performance artist Joseph Beuys's metaphor that 'everyone is an artist' by inviting the audience to contribute to the art making process. As Harvie puts it: "Delegated art and performance thus celebrate amateurism, doing art for the pleasure of it” (36). Accordingly, Smith maintains that Gob Squad actively avoid expert participant-spectators precisely because they lack authenticity, stating: "we definitely would not choose the person who looks like they're saying choose me, choose me. And that's because if they start acting up on stage they will not look good" (10). Expertise has a paradoxical relationship to participation, as it is often implied that it is neither necessary nor desirable, potentially undoing the authenticity of the work or contaminating the "leak" that Smith refers to. Simultaneously, there is a view that everyone has the expertise to get involved; thus, participation can be seen as a great equaliser.

While expert participant-spectators may not be intentionally sought after by practitioners, in reality they make up a notable share of a contemporary theatre audience and are self-made through their learnt behaviour of typified responses to participation. Therefore, it may be concluded that to avoid nurturing practised participants and an established notion of participatory performance etiquette, practitioners need to keep changing the rules or opening up 'the space of ethics' in which those rules might be reinterpreted. I suggest it is in this liminal space, permeated with the potential for failure and transgression, that participation is at its most alive.

In contrast to conventional theatre, where actors pretend to be other people, part of the appeal of audience participation in contemporary theatre is the promise of authenticity. André Antoine's assertion that we need a new breed of actors "who are spontaneous and authentic, in touch with reality through and through" 
(xvii) might well be attributed to the participant-spectators who have emerged on to the stage. In this way, the ethics of participation may suggest that a 'good' performance is interchangeable with the idea of an 'authentic' performance. Andy Lavender has noted that 'authenticity' has become one of the defining terms of contemporary performance practice (25). In The Experience Economy: A New Perspective, Albert Boswijk and his co-authors consider that "Authenticity is about rediscovering values and traditions and interpreting them in a new way within a progressive context. The individual is looking for genuineness and originality: for the core and essence of things" (46). I propose that perhaps the real art in participatory performance is being able to perform your authentic self without looking like you are performing.

While the notion of 'staging authenticity' might be argued as being inauthentic, it is essentially the combination of two different types of authenticity - stemming from the heart and the head. This hybrid form of authenticity is both emotional and logical, as the participant on stage is very much the same as their original self, but nonetheless different. On the one hand they recognise that their genuineness is sought, but on the other hand they also see the need to customise their authenticity for the audience and the performance. What is presented becomes an adjusted form of authenticity (not unlike the filtered photos on Instagram or a carefully worded Tweet), which can also be seen to correspond with Erving Goffman's concept of 'front,' discussed later.

Instead of negating the scepticism that has been imposed on delegated performance, Gob Squad's Western Society (2013; still ongoing) and War and Peace (2016; still ongoing) call attention to the exploitative potential of participation. In the summer of 2015, I attended a performance of Western Society at the Southbank Centre, London. The performance uses spectators to re-enact a barely watched YouTube video of a family karaoke party, to offer a portrait of twenty-first-century society. The later production of War and Peace develops some of the dramaturgical devices employed in Western Society. For instance, the VIP table for participants in Western Society has evolved into the salon in War and Peace. These two performances are pertinent to my analysis because a key feature within these works is the way in which they directly address ethics and self-reflexively stage and challenge their adoption of participation as a privileged form of spectatorship.

As innovators of experiments with the audience, Gob Squad's embodied assessment of participatory practice emerges from the fact that the collective is part of its trajectory, rather than a reflection of its popularity. Although Harvie warns that delegated performance may risk replicating exploitative and manipulative contemporary labour relations, she also notes that "at its best, it draws self-reflexive critical attention to that risk" (29). This echoes Bishop's contention that the 
strongest examples of delegated performances "produce disruptive events that testify to a shared reality between viewers and performers that throw into question agreed ways of thinking about subjectivity, ethics, and economics," rather than staging "the mere spectacle of participation" ("Outsourcing Authenticity” 123).

One of the ways in which Gob Squad's productions offer a self-reflexive critique of delegated performance is by emphasising participation as a place of privilege. Furthermore, the audience is made consciously aware of their complicity in the artifice and inequality of social power relations at play when participation is present. This is at its most perceptible in the VIP status that is awarded to participant-spectators in Western Society and the special treatment afforded to those invited to join the salon during War and Peace. In both instances participants are given access to a designated guest area where they are presented with champagne and other refreshments. This notable image of material privilege also converges with Bishop's observation that unlike the inexpensive performance art of the 1960s and 1970s, which was produced quickly and mostly utilised the artist's body, "delegated performance, by contrast, is a luxury game" ("Outsourcing Authenticity" 114).

This "luxury" is exemplified by interactive theatre company You Me Bum Bum Train's (YMBBT) large-scale immersive experiences for one 'passenger' at a time. Tickets average at around $£ 50$ and have become hot commodities, as they can only be purchased if the would-be theatregoer is successfully selected from a ballot. However, like both Punchdrunk's and Secret Cinema's immersive productions, this price point is a barrier for much of the public. Moreover, the perception of YMBBT as elitist is underscored further by the fact that the company actively seek celebrity endorsement, allowing high profile individuals such as Prince Harry and Madonna to bypass the usual lottery process.

In contrast, Gob Squad's performances do not profess to be immersive or a once-in-a-lifetime experience; the action tends to unfold within the duration of a few hours, supported by a simple set design that includes the use of a projection screen and a selection of props and costumes. Consequently, the tickets are on average priced at around £15; therefore, they do not actualise Bishop's notion of delegated performance as a "luxury game." Instead, works such as Western Society and War and Peace are self-consciously aware of the "game," which they play out through the theatrical device of the VIP table/salon to present a physical manifestation of participation as a place of privilege. The manner in which participant-spectators are treated as VIPs (in Western Society) serves to magnify the artificiality of their newly elevated status. As Smith states, "the VIP table is very cheap; we're being very cynical about the luxury" (6). Even so, these designated areas also have another purpose, by enabling the Gob Squad performers to have an intimate exchange with the participants, Smith explains: 
[W] want to frame their presence on the stage in a way that means we can have a real conversation, even if there's headphones and instructions and silly costumes and artifice involved. That we can exist there, and we can really be there, and when we look at each other - we see each other, and when we speak to each other - we're having an actual conversation. (7)

Yet, although this exchange may foster a closer relationship between the participant-spectators and the Gob Squad performers, it arguably has the opposite effect for the watching-spectators. As observers of the interaction between Gob Squad and the participants, we become aware that their proximity affords them special knowledge of the performance; secret conversations out of earshot and refreshments that we cannot taste. It can be difficult watching these intimate exchanges not to feel a pang of jealousy, as someone left on the outside looking in. The greater the proximity participants have to the performance, through these private moments, the further away the watching audience feels. At the same time, we are unable to forget that we might have been one of the participants and that they were once, and will be again, one of us. Therefore, as we observe our performing counterparts on stage, we are with them, albeit from a seat in the dark.

In Western Society, Gob Squad performer Sarah Thom (who founded the collective in 1992) markedly declared to the auditorium that "sometimes it's good to sit in the dark and watch." This statement prompted me to ask Smith if a spectator can be emancipated and actively engaged, as Rancière suggests, whilst staying in their seat:

Yes, unanimously yes. Before the audience gets involved in the work we still hope to work with the semi-improvisational structures ... we are live writing that work in real time and, therefore, the room is active in that writing. And that involves the audience and, therein, it feels different ... they're definitely activated even if they're just sitting there. Because they're affecting ... if they sneeze or laugh or walk out ... or not. Whether they are a small audience or a large audience ... it's felt in Gob Squad's work, it's not ignored. (Smith 8)

The semi-improvisational structures highlighted by Smith also allow the collective to offer some agency and autonomy for the participant-spectators. Even though Gob Squad's framework for participation operates within a structure that determines where the performance is going from beginning, middle to end, "there's room for play and for receiving signals from the outside" (Smith 4).

It is worth mentioning that the interpretive decisions that the performing spectator makes, such as the way in which they answer questions posed to them and how they deliver their responses, is not subject to directorial scrutiny. In the absence of editing and refinement, there are moments when their answers may feel weak and their speech uncertain, unrefined or wooden. But, instead of being condemned as a 'bad' performance, on the contrary, these hallmarks of an amateur can 
be seen to amplify the liveness and authenticity of the event: the notion that it happening in 'real-time' and with 'real' people. When we critique the performance both during and after its realisation, participation is its own criteria. By this I mean that our evaluation is less about the quality of the participant's performance, and more about their authenticity; the degree to which they committed to the task; and how their participation translated into meaning and experience.

The Q\&A segments that are interspersed within the fabric of both Western Society and War and Peace is a clear example of the way that Gob Squad are "live writing" the work, as well as making visible the conception of performance as a space for ethics. Questions such as "Do you believe in progress" and "What is the name of the first French suicide bomber" posed by Gob Squad performers to participants (War and Peace) bring into being "the staged and the spontaneous" (Bishop, "Outsourcing Authenticity" 121). A degree of authorial control (the questions) is fundamental to the structure of the exchange, but the end result is largely reliant on the skills of the participant to meet or even exceed the expectations of Gob Squad and the viewing audience.

Nevertheless, the artificiality of the theatrical setting, and the close-up shots of the participant seen on the projection screen (War and Peace), all at once frame participation and draw attention to the inauthenticity of the participant's spontaneity (Bishop, "Outsourcing Authenticity” 121). This underscores my earlier statement that the art of spectator-participation resides in the participant's ability to stage their spontaneity while holding on to their authenticity. As Bishop notes, some of the most powerful instances of delegated performance are those that “permit 'authenticity' (subjects that are engaged, passionate, fragile, complex) to emerge within situations of intense artificiality" ("Outsourcing Authenticity” 120). Additionally, the proximity of performers and participants, most notably during the Q\&A scenes, can be said to challenge relational oppositions by unsettling the previously established 'us' and 'them' divide between theatre performers and spectators. At the same time, as David Beech notes, this may establish a new 'us' and 'them' in the form of those that do and those that don't participate (25).

\section{Ethics and the Spectator Within}

Building on the understanding that ethics and authenticity both frame and complicate participatory performance, I will now take a closer look at the internalised set of values that guide one's ethical behaviour in the situation of participation. Building on Ridout's theorising, my analysis will outline a double dimension to the ethics of participation: the first is concerned with the self, and the second is about everyone else. 
Beginning with the self, Ridout draws on philosopher Adam Smith's (1759) writing to suggest that "we judge our own behaviour in the guise of an imaginary 'spectator' within us" (Ridout, Theatre and Ethics 33). The principle that underlines this concept is that we each possess an "impartial spectator" (35) inside ourselves, and it is to them that we direct our behaviour for ethical judgement. Our perception of whether or not the 'spectator within' approves or disapproves of our actions will determine whether or not we consider our behaviour to be right or wrong. In addition, as Ridout elucidates, a "doubling of the self" into "the one who judges and the one whose actions are judged" requires an emotional connection to oneself and an element of disconnection which enables enough distance for reason to emerge (35). Reflecting on my own experiences of participation, I propose that the spectator within also has a capacity to speak directly to us ("go on take a risk") or to express our inner feelings ("don't pick me").

Furthermore, this inner spectator is often influenced by a process of "introjection" in which they internalise "once prescribed and now habitual behaviours carried by us all” (Heddon, Iball and Zerihan 125). These introjects frequently guide our moral compass and illustrate how one should act. Indeed, as Heddon and her co-authors have observed, “[c]ommitment to our 'introjects' ('I should be, I must be, I ought ...') can be so strong that they often have the power to override our interest in our own well-being” (125).

Moreover, another influencing factor emerges from the way that participation is in many ways extorted from the audience, demanding "a 'special complicity' with an aesthetic situation," as Alston has argued (“Audience Participation” 129; see also Fried 127). Hence, the spectator within may feel further compelled in the situation of participation to prioritise the performance above their own welfare and in spite of their fears. In turn, this raises the question of who should assume ethical responsibility and care for the spectator during and after their participatory experience, and in the event of 'participation gone wrong.'

There are also times when an introject clashes with our original impulse; thus, what we want to do and what we think we should do are at odds with each other. This can result in the participant offering an expected rather than a truthful response. Looking back on my experience as an audience member at War and Peace, it is this clash that gave rise to a feeling of inadequacy, as my impulse not to participate conflicted with the introject that I must 'give good audience.' During the opening sequence when performers introduced potential participants on stage, I noticed Gob Squad's Simon Will close at hand, and I actively avoided making eye contact with him. As a feeling of foreboding gathered in the pit of my stomach, three words ran through my mind endlessly repeating: "Don't pick me." I questioned what I would say about myself; the truth, or a better, funnier version of the truth? I reasoned that it would be easier and safer to remain seated in the 
auditorium. Later, my trepidation towards participation would be validated, but at the time I was a little disappointed in myself. The omnipresence of the ideal spectator is never far away, beseeching me to cede my will and forget my fears.

Additionally, developing Ridout's theorising, I suggest that there is an 'ideal spectator within' that speaks to the interrelationship between how we want to be perceived and our ethical compass. In the example of War and Peace, the first appearance of my 'ideal spectator within' occurred when I purchased my ticket. It is often at this moment when we must decide where we would like to be positioned in relation to the performance, and perhaps how we would wish to be seen. Tickets were priced between $£ 14-16$ and I selected the slightly more expensive seats, close to the front row. I recognised that my proximity to the performance might increase the possibility of being chosen to participate, and I sought to present an idealised impression of myself as one that would 'give good audience.' As Goffman reflects, citing sociologist Charles Cooley: "If we never tried to seem a little better than we are, how could we improve or 'train ourselves from the outside inward?"” (Goffman 44).

It is at this juncture that I wish to introduce Erving Goffman's notion of 'front,' outlined in The Presentation of Self in Everyday Life (1956), as a useful concept in establishing how impression management is a vital constituent in the ethics of participation. Goffman determines that the impression given by an individual to observers is decided by "the expression that he gives, and the expression that he gives off' (14, emphasis original). In the first instance an impression is given through the use of recognisable signs to convey information about one's character to others. In the second occurrence the sign activity is indicative of the character, or given off rather than intentionally expressed. However, it should be noted that an individual can deliberately misinform their audience through the signs that they give and give off, by way of deceit or feigning (Goffman 14).

Goffman employs the term 'front' to define the largely fixed element of an individual's performance which works to manage the impression being made on those observing (32). He suggests that the performance of front can be divided into parts, which include setting, appearance and manner: "setting" refers to the scenery and stage props that frame the performance of front; "appearance" concerns those personal signs which indicate the individual's social status; and "manner" relates to those signs which are indicative of the role that the individual expects to have in the unfolding event (Goffman 32-35). What is more, Goffman acknowledges that we often expect some coherence between these three components of front (35). In other words, how an individual expresses themselves is typically governed by the concurrent tendencies of where they are, their social standing, and how they expect to be treated. It could also be said that relations amongst these three factors provide the basis on which the spectator within selects the individual's social front and critiques the performance. 
For Goffman, "fronts tend to be selected, not created" (38), and "become institutionalised in terms of the abstract stereotyped expectations to which [they give] rise" (37). This notion resonates with the argument that as participatory performance develops into a popular art form, it becomes entrenched with preconceived ideas of how spectators should act. Therefore, the audience is likely to find that there is a predetermined selection of fronts from which to choose, the most recognisable of which are the watching-spectator and the participant-spectator, although these positions will also be divided into a further assortment of fronts.

Reflecting on my presence in the audience for War and Peace, as opposed to maintaining consistency between the varying parts of my front, my appearance and manner arguably contradicted each other. The decision to purchase seats close to the stage gives the impression of a social status that is imbued with a desire to be seen, whereas my manner - avoiding the searching gaze of performers in pursuit of willing participants - gives off a lack of confidence and a wish to be left alone. However, despite my attempt to put on the front of an ideal spectator, this impression was undermined by my overanalysis of the situation. Echoing Rachel Gomme's reflections on encountering one-to-one performance, my experience is already being defined by "my own preconceptions, including, for myself as seasoned spectator, a degree of critical detachment" (289). I concede that the more knowledgeable about participation that I have become - its potentialities, limitations, expectations and risks - the less I am inclined to accept the invitation. However, as I have previously discussed (see Jordan 112-113), there are 'expert participant-spectators' who foster a greater attachment to participation precisely because of their accumulated experiences.

The artifice of social fronts is one of the themes explored in War and Peace, most strikingly in the highly theatrical manufacturing of the fronts presented by Napoleon, the Russian Tsar and Pierre Bezukhov, as we see their appearance and manner altered to affect the impression that each of them gives and gives off. Also, participant-spectators' contribution to live writing the performance during the Q\&A sections is dependent on their inbuilt capacity to make judgements about their front and to adapt it accordingly: to evoke their spectator within.

In the next part of my analysis, I will discuss how this process of ethical judgement is mirrored in the watching-audience, who empathise with their performing counterparts. It will examine how a relational dimension to participatory performance shifts ethical responsibility away from being only about the self and towards an ethical responsibility for someone else. As Ridout considers, "ethics might in fact be all about everyone but yourself” (Theatre and Ethics 13). 


\section{Ethics as Encounter}

Emerging from Emmanuel Levinas' writing on ethical thought, Ridout constructs the concept of 'ethics as encounter' (see Levinas, Totality and Infinity; Levinas Reader). He maintains that Levinasian ethics applied to performance "encourages the spectator to stop seeing the performance as an exploration of his or her own subjectivity and, instead, to take it as an opportunity to experience an encounter with someone else" (Ridout, Theatre and Ethics 8). Clearly, this is a philosophy that is epitomised in practice where an encounter with another is at the centre of the work, such as in one-to-one performance. But it is also a belief which is fostered in Gob Squad's use of participation to strengthen the bond between those on stage and those in the auditorium. As Smith distinguishes, this connection between participant-spectators and watching-spectators is expressed as

the ability to relate to that person because they've left one part of the auditorium and they've gone to another part of the room ... they've crossed over that line. And they've kind of taken a little bit of the audience with them, so there's a certain sort of extension of themselves maybe into the performance space. (3)

In my examination of the 'spectator within' and Goffman's notion of 'front' I have talked about the way in which impressions of the self are managed. I now wish to offer a second conception of the term 'impression,' interpreted by Ridout as a form of physiological communication between people which in turn underpins empathy.

Following Ridout, due to the fact that on the whole humans possess comparable qualities and feelings, an understanding of someone else's situation can 'impress' itself on an individual's own person. Ridout writes that in this doubling process, what someone else is doing or feeling “is 'impressed' upon me; it is like the action of a printing press on the surface of a body. As a result of this impression, I experience the feeling along with the other person. Literally, I feel the same thing [...] from one body to another" (Theatre and Ethics 34). For Ridout, it is this embodied connection that enables us to feel satisfaction when we perceive someone doing something good, or dissatisfaction when they imprint an act of wrongdoing (34). On this basis, it is in our encountering of one another that human beings establish "a capacity for ethical judgement which is a natural extension of their existence as physiological beings" (34-35). It might be supposed that our predisposition for empathy underlies our spectator within, as an inbuilt mechanism for assessing the way in which one might be judged by those on which one may impress. This implies, as Ridout muses, that ethics is always in the end about someone else.

Indeed, an example of the interdependency between individual and relational ethics is actualised in the way that participants improvise during the Q\&A 
sections within Gob Squad's performances. In these moments, the participants will instantly separate themselves into two roles; first, they need to assess how to respond to the question; secondly, they must refer their response inwards to the spectator within. For the spectator within, this is a self-reflexive process based on their previous communication with others. In short, 'ethics as encounter' fuels the ethical judgement within us. In an interview situation, there is an almost instantaneous process of improvising our answer and filtering that answer based on the impression that we would wish to make. This process coincides with the duality of emotion and reason that underscore ethical judgement. Of course, there are times when our ability to be spontaneous hinders the effectiveness of our impression. There are also instances when our inner spectator gets it wrong, which might occur when we are not familiar with the other people that are in attendance, thus, misjudging what the reception will be. Then there are those occasions when an individual wilfully goes against the ethical code generally accepted by others, as discussed later in the article.

In the context of the theatre, I wish to propose that empathy as a process of identification with another is made stronger when the person on stage belongs to the same 'team' as the watching-spectator. Contemplating audience participation in Gob Squad's productions, Smith remarks, “once somebody does go in, you tend to think about yourself don't you? Like how would I feel if that was me ... you're on the same team ... you're kind of gunning for them" (7-8). The concept of 'teams' is usefully explored by Goffman, who uses the term "to refer to any set of individuals who cooperate in staging a single routine" (85). In this way, the audience can be understood as a team, even if the team-mates perform varying roles on a continuum of interactivity.

For Goffman, "whether the members of a team stage similar individual performances or stage dissimilar performances which fit together into a whole, an emergent team impression arises" (85). In addition, it is clear that members of the same team will have a notable relationship to each other, as each member is reliant on the good behaviour of their team-mates, establishing a "bond of reciprocal dependence" (88). Furthermore, this cooperation is reinforced by a given "reciprocal familiarity," which "is automatically extended and received as soon as the individual takes a place on the team" (88). However, Goffman stresses that should a person go outside the boundaries of acceptable team behaviour or what we might call ethics, "giving the show away or forcing it to take a particular turn," they are still considered part of the team (88). This reinforces my assertion that even when spectators cross the border and undertake a performance role, they are nonetheless part of 'team audience.'

Moreover, part of the performing participants' dramatic effect derives from the fact that they appear to be acting beyond the pale of their team's typical be- 
haviour; consequently, the other audience members are compelled to reconsider their own conduct. Nevertheless, I suggest that on the other side of the border the participant-spectators form a new team, which complicates rather than abolishes their membership of team audience. This is contrary to the view that the participants temporarily join the team of company performers, which I refute on the basis that they are only given access to the 'front region' of the performers' territory. Goffman uses the term 'front region' to describe the place where the performance is staged and 'back region' as an area that knowingly contradicts the performance given out front. He observes that it is in the back region that the production is assembled, where "illusions and impressions are openly constructed" (Goffman 114). Even when the stage includes part of the back region, as we find in the VIP/salon area of Gob Squad's performances, where the performers can be observed removing parts of their costume (Western Society), taking refreshments and chatting off script, it is a theatricalised presentation of behind the scenes and not the backstage proper.

In Goffman's hypothesising, the constitution of a team, with its "reciprocal dependence," cuts across social and political divides. Similarly, in Western Society, Gob Squad make reference to the participants as people who are sharing in this unique experience together; people who otherwise may not come into contact; people who have left their theatre companions behind to form new bonds in the "new world." The evolving party on stage becomes a temporary utopia, where cultural and social preconceptions no longer have relevance. In the newly formed team of participants an impression is quickly established, albeit one based on 'special complicity' and 'giving good audience.'

However, as I have intimated, this new team formed in the new world does not deny the pre-existing team from which they came: team audience. Furthermore, according to Goffman, when two teams come into contact they tend to maintain their established appearance, as well as supporting the impression that the other team are keen to uphold. At the same time, the relationship between the teams may be reorganised during moments of crisis (Goffman 166), and there are times when performing-spectators and watching-spectators can deviate from the agreed team impression.

\section{Participation Gone Wrong and Dis-spectatorship}

In general, artists do what they can to limit the possibility of participation going wrong, which typically includes some kind of informal casting. In War and Peace this process was made explicit through the initial interviews with audience members; however, in spite of an artist's best efforts, there are times when miss-cast- 
ing occurs, possibly where a person's 'front' has been feigned or misread. The result is various forms of transgressive spectatorship.

As I disentangle 'participation gone wrong,' I arrive at three types of transgressive spectatorship; Ridout's 'mis-spectator,' Alston's 'errant spectator,' and my own category of the 'dis-spectator.' Ridout identifies the 'mis-spectator' as an audience member whose lack of expertise leads them to misinterpret a performance and to react in a way that is outside of typical audience behaviour. However, corresponding with Bishop's call for 'antagonism,' Ridout proposes that “a measure of inexpertise may be crucial to an interruption of the consensus around value to which experts, both performance makers and spectators, routinely contribute, a consensus in which we agree only to see and hear what we already know" ("Misspectatorship" 173). Similarly, Alston suggests that a spectator's mistakes are not always to the detriment of the performance and can be "mistakes that make" ("Making Mistakes" 67, emphasis original). He distinguishes the 'errant spectator' to define a participatory audience member who has strayed from the intended course of action ("Making Mistakes" 65), which emerges from "a surplus of expertise, reading too well and taking too far an invitation to get involved" (67). I suggest that expertise can be a source of audience fear, both in terms of a lack and a surplus. Fear of not knowing what to do, of getting it wrong or doing it badly. Fear of knowing too much, of recognising the tactics and the predetermined result and performing too well, undermining the expected genuineness of one's participation.

It is at this stage in the paper that I will turn to the conspicuous example of participation gone wrong that I witnessed during War and Peace the likes of which I have not seen before or since. This moment interrupted the consensus of the audience and represented a crisis in the ethics of participation. It could be said that the trouble began in the casting, or what might be considered mis-casting, as over the course of War and Peace it transpired that one of the chosen participant-spectators had been a political party candidate during the previous general election. Therefore, when Gob Squad's Simon asked the participant a series of questions, she offered very full responses and seemed to have her own agenda, taking up quite a lot of stage time and appearing difficult for him to rein in. This prompted a group of three audience members, who were sitting in front of me, to heckle her, shouting comments and insisting that she speed up her answers.

I propose that the three hecklers demonstrated the behaviour of what I have termed the 'dis-spectator.' Unlike the errant spectator or the mis-spectator there is nothing mistaken about the conduct of the dis-spectator. I suggest that an invitation to participate can bring out the 'dis-spectator within us,' especially when fuelled by what Alston has referred to as a hedonistic and narcissistic desire for participation (“Audience Participation” 130). This form of transgressive spectatorship exists on a continuum (see Figure 1). 


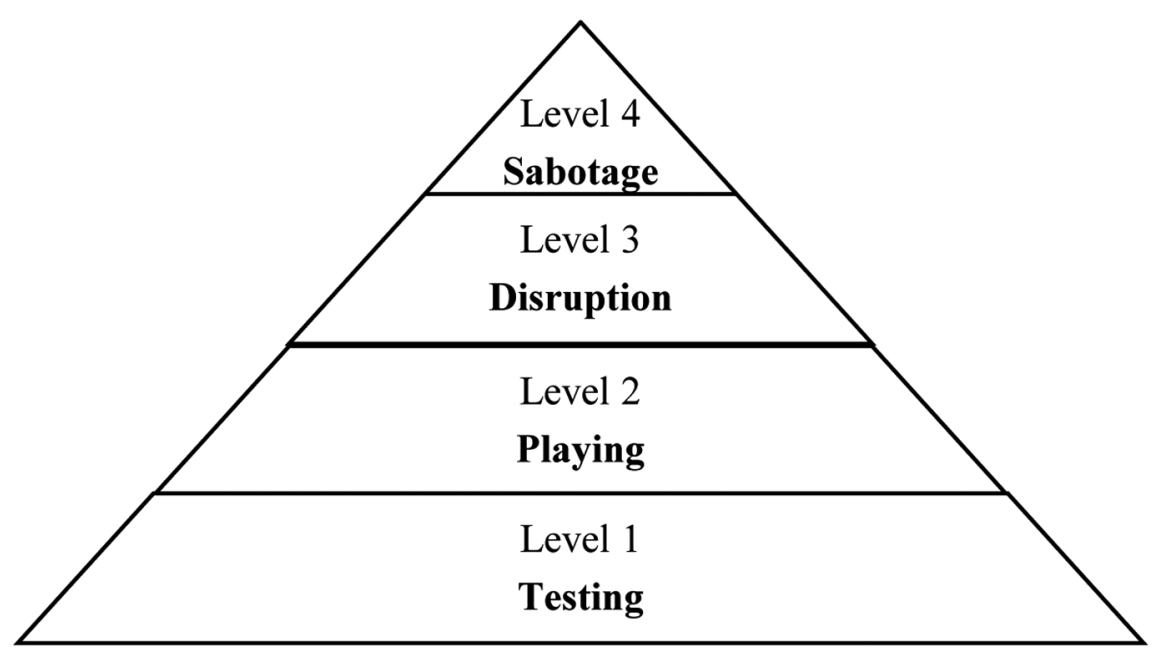

Figure 1: Taxonomy of Dis-spectatorship

At level 1: 'Testing,' the dis-spectator displays low-level dissent from their fellow spectators. They might be seen questioning an immersive performer on their back story to try to catch them out or checking for potential weaknesses and ambiguities within the parameters for participation.

At level 2: 'Playing,' the dis-spectator has dissented further from the rest of the audience through their desire to lightly experiment with the framework for participation out of a sense of mischief. Rather like the "High Places Phenomenon" (Hames et al), where one gets a sudden compulsion to jump when they are in a high place, some spectators get an impulse to be disobedient in the situation of participation. If "[a]n urge to jump affirms the urge to live," as the title of Hames and her co-authors' study suggests, I propose that an urge to play affirms the urge to perform. Level 2 dis-spectators are frequently fellow artists and performers and will almost certainly volunteer themselves if participation is invited. However, while they may play with the rules for participation, they are careful not to upset the structure in such a way that it may negatively impact the performance.

Conversely, dis-spectators that operate at level 3: 'Disruption' deliberately and visibly rebel against the performance, redirecting the focus to their agenda but stopping short of undoing the performance altogether. An infamous example of level 3 dis-spectatorship was displayed by Jarvis Cocker during his 1996 BRIT Awards invasion of Michael Jackson's performance of "Earth Song." While his moment of protest was disruptive, it did not prohibit the performance from continuing. This example is also indicative of the way in which this taxonomy might 
usefully be applied to other instances of performance outside of participatory practice.

At the highest level 4: 'Sabotage,' the dis-spectator attempts to stage an intervention that threatens to unravel the whole performance. Instigators of riots and acts of terror during performance constitute level 4, although relentless heckling may also incapacitate a production if the performer(s) become too distracted.

In War and Peace, the dis-spectators corresponded with the third level of the continuum, as their behaviour was focused on disrupting one participant rather than bringing down the entire show. Yet, the disorderly conduct of the hecklers created a palpable tension within the auditorium, which crossed the border into the performance. It was apparent that neither the audience nor the performers knew what to do. And, it would be dishonest if I didn't admit that there was something thrilling about watching this crisis unfold: witnessing Simon struggling to rein in the overzealous interviewee at the same time as attempting to ignore the shouts from the disgruntled trio. It magnified the liveness of the experience and arguably reconfigured the performance as a space for discord and 'antagonism.'

Audience members and Gob Squad performers alike were compelled to question who is responsible for the performance; who is responsible for the participant-spectator; who is responsible for the hecklers; how do we bring resolution to this situation; do we want to resolve this situation or is this what we have been waiting for? After all, as Ridout tells us: "Theatre's greatest ethical potential may be found precisely at the moment when theatre abandons ethics" (Theatre and Ethics 70). Nonetheless, despite the revolutionary possibilities, I found the convergence of the 'emancipated spectator' into the 'abandoned spectator' troubling, and I empathised with my team member on stage. Thankfully the participant appeared unmoved by the abuse directed at her; no doubt a thick skin earned through her campaigning as a politician.

Analysing more closely the newly formed team of dis-spectators, and putting aside the possibility that the hecklers knew her in some way, I suggest that the participant's front indicated a lack of authenticity or vulnerability. In this way, her professionalism denied the audience the celebrated impression of the amateur as an artist. However, although the participant's appearance and manner suggested an expert participant-spectator, her apparent inability to underplay her public front denotes inexpertness. Whether cast as an errant spectator who surpassed her role, or as a mis-spectator who overestimated how much to say, perhaps in the eyes of the hecklers she threatened the consensus of the performance. To this end, we may conclude that the hecklers sought to reclaim control of the performance for the audience, but also on behalf of the performers - to break in order to make. Alternatively, perhaps they were objecting to the way that her pro- 
fessionalism and front undermined the authenticity of participation. Following Goffman, it may be that their interruption was intended to reprimand their team member for going outside of the typical standards of participation, even if this created further disharmony in the performance.

Though I want to stress that the situation of hecklers in War and Peace is very rare, for me it evidences that the ethics of participation remains contested ground, fraught with conflicting notions of responsibility and impression management. It was striking that no-one intervened when the dis-spectators collectively berated the participant-spectator, not the audience, not Gob Squad, and not the theatre ushers. I argue that if a 'special complicity' is demanded of participants, special care should be afforded to them. As interactive theatre makers Persis Jade Maravala and Jorge Lopes Ramos of ZU-UK have asserted, the management of an active audience "would benefit from more rigorous investigation and care." In my attendance at participatory performances over the last ten years, the only aftercare that I have witnessed is in the form of the ad hoc "how was it for you?" chat between artists and participants in the bar/cloakroom afterwards. More often than not, any provision of ethical responsibility for the participant ends once the experience is over.

I propose that theatre makers have an ethical responsibility to take care of their spectators during and after their participatory experience. Examples of good practice in this regard include YMBBT's use of a recognisable distress code that 'passengers' should employ if their experience becomes too much, in the form of a simple T-shape hand sign accompanied by the words 'time out' spoken three times (Lawson). Also Tassos Stevens, director of interactive theatre company Coney, advocates creating a space for participants to decompress post their participatory experience. Indeed, there is a need for greater dissemination of these kinds of practical strategies in the responsible management of audience participation for all stages of the performance process.

In conclusion, over the course of the discussion I have offered a theoretical framework for understanding the ethics of participation, drawing particularly on the critical concepts of Ridout and Goffman. In doing so, I have shown how the ethics of participation is a mutable construct that is about one's own subjectivity, and at the same time about our encounters with others. This double dimension is further complicated by the way that impressions are managed and embodied through the front that we give and give off and the 'team(s)' to which we belong. If there is one attribute that the ethics of participation insists upon, it is the capacity to spontaneously stage one's authentic self. This serves as a reaction and resistance to the concurrent dominance of social media where impressions are filtered on Instagram and fronts are managed through Facebook updates and retweets. 
My analysis has recognised how the ethics of participation increases the jeopardy in performance, bringing into view participation gone wrong and the emergence of the mis-spectator, the errant spectator, and the dis-spectator. I have outlined a taxonomy of dis-spectatorship to categorise the varying levels at which audience members can challenge the framework for participation, from 'testing' the structure to 'sabotage.' Yet, I contend that a degree of ethical promiscuity is part of participation's vitality, which is in danger of being compromised if the etiquette of engagement becomes too formulaic and spectators' responses learnt. Importantly, as Gob Squad illustrate, participation has the capacity to enable strangers to meet and new political and social realities to emerge (if only for the duration of the performance). Even so, just as Tolstoy's War and Peace looks at how one might live an ethical life in an ethically imperfect world, Gob Squad's War and Peace reveals the precarious relationship between ethics, participation and performance.

\section{Works Cited}

Alston, Adam. "Audience Participation and Neoliberal Value: Risk, Agency and Responsibility in Immersive Theatre.” Performance Research 18.2 (2013): 128-138. Print.

Alston, Adam. "Making Mistakes in Immersive Theatre: Spectatorship and Errant Immersion." Journal of Contemporary Drama in English 4.1 (2016): 61-73. Print.

Alston, Adam. Beyond Immersive Theatre: Aesthetics, Politics and Productive Participation. Basingstoke: Palgrave Macmillan, 2016. Print.

Antoine, André. "From The Free Theatre." 1890. Twentieth-Century Theatre: A Sourcebook. Ed. Richard Drain. London: Routledge, 1995. Xvii. Print.

Aragay, Mireia and Enric Monforte. Ethical Speculations in Contemporary British Theatre. Basingstoke: Palgrave Macmillan, 2015. Print.

Beech, David. “Don’t Look Now! Art after the Viewer and beyond Participation.” Searching for Art's New Publics. Ed. Jennie Walwin. Bristol: Intellect, 2010. 15-31. Print.

Bishop, Claire. "Antagonism and Relational Aesthetics.” October 110 (2004): 51-79. Print.

Bishop, Claire. Participation. London: Whitechapel, 2006. Print.

Bishop, Claire. "Outsourcing Authenticity? Delegated Performance in Contemporary Art.” Double Agent. Eds. Claire Bishop and Silvia Tramontana. London: Institute of Contemporary Arts, 2008. 110-125. Print.

Bishop, Claire. Artificial Hells: Participatory Art and the Politics of Spectatorship. London: Verso, 2012. Print.

Boswijk, Albert, Thomas Thijssen, and Ed Peelen. The Experience Economy: A New Perspective. Amsterdam: Pearson Education, 2007. Print.

Fisher, Tony. "Radical Democratic Theatre." Performance Research 16.4 (2011): 15-26. Print. Fried, Michael. "Art and Objecthood.” Minimal Art: A Critical Anthology. Ed. Gregory Battcock. New York: Dutton, 1968. 116-147. Print.

Georgia, Claudia. Liveness on Stage: Intermedial Challenges in Contemporary British Theatre and Performance. Berlin: De Gruyter, 2014. Print. 
Gob Squad. “About Us.” Gob Squad Arts Collective GmbH, n. d. Web. 9 May 2019. <gobsquad. com/about-us>.

Gob Squad. "Current Projects, War and Peace." Gob Squad Arts Collective GmbH, n. d. Web. 27 July 2019. <gobsquad.com/projects/war-and-peace>.

Goffman, Erving. The Presentation of Self in Everyday Life. 1959. London: Penguin, 1990. Print. Gomme, Rachel. "Not-so-close encounters: Searching for intimacy in one-to-one performance." Participations: Journal of Audience and Reception Studies 12.1 (2015): 281-300. Print.

Hames, Jennifer, Jessica Ribeiro, April Smith, and Thomas E Joiner. "An urge to jump affirms the urge to live: an empirical examination of the high place phenomenon." Journal of Affective Disorders 136.3 (2012):1114-1120. Print.

Harvie, Jen. Fair Play: Art, Performance and Neoliberalism. Basingstoke: Palgrave Macmillan, 2013. Print.

Heddon, Deirdre, Helen Iball, and Rachel Zerihan. “Come Closer: Confessions of Intimate Spectators in One to One Performance." Contemporary Theatre Review 22.1 (2012): 120-133. Print.

Heim, Caroline. Audience as Performer. London: Routledge, 2016. Print.

Jordan, Kelly. "On the Border of Participation: Spectatorship and the 'Interactive Rituals' of Guillermo Gómez-Peña and La Pocha Nostra." Journal of Contemporary Drama in English 4.1 (2016): 104-118. Print.

Lavender, Andy. Performance in the Twenty-First Century: Theatres of Engagement. London: Routledge, 2016. Print.

Lawson, Mark. "You Me Bum Bum Train: my trip with the Kafkaesque theatrical cult." The Guardian, 23 Sep. 2015. Web. 6 Aug. 2019. <theguardian.com/stage/2015/sep/23/you-me-bumbum-train-my-trip-with-the-kafkaesque-theatrical-cult>.

Levinas, Emmanuel. Totality and Infinity: An Essay on Exteriority. 1961. Trans. Alphonso Lingis. Pittsburgh: Duquesne University Press, 1969. Print.

Levinas, Emmanuel. The Levinas Reader. Ed. Seán Hand. Oxford: Blackwell, 1989. Print.

Maravala, Peris Jade and Jorge Lopes Ramos. "Immersive Theatre: Towards a Dramaturgy of Participation.” Exeunt Magazine, 2nd May 2016. Web. 6 Aug. 2019. <thetheatretimes.com/immersive-theatre-towards-a-dramaturgy-of-participation/>.

Rancière, Jacques. “The Emancipated Spectator.” Artforum International 45.7 (2007): 271-280. Print.

Rancière, Jacques. The Emancipated Spectator. Trans. Gregory Elliott. London: Verso, 2009. Print.

Reason, Matthew. "Introduction to Part 2: 'Participations on Participation: Researching the "active” theatre audience." Participations: Journal of Audience and Reception Studies 12.1 (2015): 271-280. Print.

Ridout, Nicholas. Theatre \& Ethics. Basingstoke: Palgrave Macmillan, 2009. Print.

Ridout, Nicholas. "Mis-spectatorship, or, 'redistributing the sensible." Archaeologies of Presence: Art, Performance and the Persistence of Being. Ed. Gabriella Giannachi, Nick Kaye, and Michael Shanks. London: Routledge, 2012.172-182. Print.

Smith, Sharon. Personal Interview. 1 July 2016.

Stevens, Tassos. "Making Play." Audience, Experience, Desire: Interactivity and Participation in Contemporary Performance \& the Cultural Industries. University of Exeter, UK. 30 Jan. 2016. Unpublished Conference Paper.

White, Gareth. Audience Participation in Theatre: Aesthetics of Invitation. Basingstoke: Palgrave Macmillan, 2013. Print. 